\title{
The U.S.-Russian Dispute Over Missile Defense
}

\section{Vladimir Rukavishnikov *}

\section{Introduction}

The current Bush Administration is considering a crash effort to put into place the European components of a U.S.-built national missile defense system (NMD) before the end of President Bush's second term. While the debates in the United States are focused primarily on the failure and success of various flight tests, and on the cost of missile defense, the European general public wants to see a concrete plan of its deployment, to understand the design of the entire system, and have a clearer sense of a timetable.

The European part of the U.S. anti-missile shield consists of interceptor missiles in Poland and radar installations in the Czech Republic linked with them. Initially, President George W. Bush's missile defense plan had met with muted support at best in Central Europe, but the situation changed dramatically in short order, because the U.S. offered its partners a tremendous carrot-namely, significant help in modernizing the Polish armed forces, investments in the Czech Republic - along with the stick of exact obedience from these new NATO members.

There is no doubt that the new U.S. bases in Poland and the Czech Republic will become a reality sooner rather than later. The ruling elites of these nations think that, as in the Cold War era, the Americans are playing a paramount role in guaranteeing Europe's security from what they view as "a common enemy.",

Some Americans may feel pride or even a bit of condescension in this dependency on the part of Poland and the Czech Republic. Indeed, it costs the United States less to defend its interests in Europe if these two Central European countries are more closely tied to the U.S. ${ }^{2}$

Prof. Dr. Vladimir Rukavishnikov currently is an independent expert-consultant, based in Russia. He was the Head of the Department of Social Dynamics in the Institute of SocioPolitical Research at the Russian Academy of Sciences in Moscow, and a professor in the Department of Global Politics in the Higher School of Economics at the State University of Moscow.

1 I do not agree entirely with the opinion of some colleagues of mine that "Central Europeans lost self-confidence through two world wars and self-reliance in the Cold War, and now they find it easier to defer to the United States in the issue of missile defense (private communication). This arrogant opinion does not constitute a correct explanation for current policy decisions. Yet we do agree that the mixed reaction of public opinion to the Bush proposal reflects a fear of the Russian bear which is still widespread among parts of certain Central European elites.

2 In the United States, the public's attitude toward particular foreign policy issues depends primarily on the degree to which the policy advances the American national interest, whether such a policy involves the use of military force, and how much it costs, among other factors. 
Political changes in both Russia and the United States in 2008 are raising questions about the continuation of the missile defense dispute, since the outcome of these elections is not clear at this time. However, we do not think that the next U.S. administration will abandon Bush's effort to station interceptors' bases in Europe. Russian experts are certain that the announced limited number of interceptors with a radar station to guide them represent only a small part of what the U.S. military envisions as an end state. The consequences of this "provocative action" must not be underestimated (or so these Russian experts say), but nobody knows exactly what is really implied by these threatening words.

\section{The Beginning of the Story}

This story began in May 2001, when the U.S. President George W. Bush announced plans to pursue a stepped-up national missile defense program (NMD). Mr. Bush said that small rogue nations were developing nuclear bombs and chemical weapons, and therefore posed a greater threat to the West than Russia and China. ${ }^{3} \mathrm{He}$ also said that the National Missile Defense system should protect U.S. citizens from missiles launched by any country, and that his administration hoped to develop such a system. ${ }^{4}$

According to a widespread view, the NMD project is a logical continuation of the Reagan-era Strategic Defense Initiative, or "Star Wars" program, as the missile defense program announced in the early 1980s was called. It should be noted that in September 2000, before leaving the White House, then-President Bill Clinton announced that he would not go ahead with the development of national missile defense system, deferring any decision to his successor, George W. Bush. The truth is that, at that time, if an attack had been launched against the United States, the U.S. military would not have been able to protect their national territory from incoming ballistic missiles, especially those with multiple warheads.

Clinton's decision was welcomed by President Putin, who said that it was seen in Russia as "a well-thought and responsible step." 5 The Russian military were more skeptical concerning postponing of the development of NMD. The defense ministry's official spokesman, three-star General Valery Manilov, the first deputy chief of staff of the Russian armed forces, told reporters in an interview with Russian television that Clinton's NMD postponement was "a false-bottomed suitcase."

3 According to U.S. sources, by the end of the previous century there were some 20-25 countries other than Russia and China that were suspected of developing or acquiring ballistic missiles that could be used in an attack either on U.S. or allied troops overseas or on United States territory. The list of so-called rogue states at that time was much shorter (the "nations of concern” were North Korea, Iraq, Libya, and Iran).

4 President G. W. Bush made this hope clear in a speech on 1 May 2001; see "Remarks by the President to Students and Faculty at National Defense University," available at www.whitehouse.gov/news/releases/2001/05/text/20010501-10.html.

5 This quotation is from the official statement of the Kremlin, and is available at www.mid.ru; it can be found in the data archive. 
For the Russian generals, the NMD proposal, its “Star Wars” predecessor, the Theater Missile Defense (TMD) Program, which was developing in parallel, and other similar projects were all equally dangerous. The Russian military analysts viewed them as efforts aimed at reinforcing U.S. missile and high-tech arsenals, in order to build a modern umbrella to shield U.S. conventional and nuclear forces. ${ }^{6}$

On 13 June 2002, the United States withdrew from the 1972 Anti-Ballistic Missile (ABM) Treaty with Russia, which banned the deployment of missile defense systems outside the national territory. The U.S. withdrew from the treaty because, in order to be effective, missile defense systems should be deployed as close to the trouble spot as possible, not because the treaty was simply a Cold War relic.

Today, the 1972 ABM Treaty limitations are invalid. ${ }^{7}$ That is why the U.S. can deploy elements of the missile defense system in Central Europe, where the so-called third positioning area of the U.S. ABM system is currently located. For a long time the Russians resisted changing the 1972 ABM Treaty, although they agreed that after the demise of the USSR it was rendered archaic. Although the Soviet Union-the United States' partner in the 1972 ABM Treaty-no longer existed, as its successor state Russia kept all treaty commitments until the U.S. unilaterally withdrew from the ABM Treaty in 2002. The ABM treaty was critical to Russia as a confirmation of its status in the international arena, despite its loss of superpower status following the collapse of the Soviet Union.

The Russian Federation readily raised its voice against the unilateral U.S. withdrawal from the treaty, but that was all its leaders could do, along with making promises to upgrade the country's strategic forces. ${ }^{8}$ The U.S. president and his advisers tried to justify their decision, but all attempts to persuade the Russians failed, given their strong opposition to the idea of deployment of components of U.S. anti-ballistic missile system outside of U.S. territory. The United Sates was not ready to forgo building an interceptor site in Europe, while Russians insisted on such a site's unacceptable nature. The Russians offered to use their radar installations in Azerbaijan as a joint early-

6 This point of view has still not changed significantly, even today. It matches that of Richard N. Perle, who had responsibility for the Strategic Defense Initiative as assistant secretary of defense in the Reagan Administration. This famous proselytizer for missile defense wrote recently: "Without any missile defense-our current situation-we are vulnerable to any country or movement that manages to obtain even a single missile capable of reaching the United States. Our allies and troops abroad are in greater jeopardy because shorter-range missiles, which are already available, can reach them.” (Richard N. Perle, "The Arms Race Myth, Again,” The Washington Post, 3 March 2008; A17; the citation has been taken from the version of the article posted on washingtonpost.com).

7 The US Congress had not ratified the 1997 additional protocol, which bound the START II Treaty to the 1972 ABM Treaty.

8 Moscow's response, delivered in a statement by President Vladimir Putin, expressed disagreement with the U.S. decision but simultaneously emphasized the Russian official diplomatic position that the United States is not a threat to Russia. Putin also talked about speeding up the reform of Russia's strategic forces. See S. Kortunov, "Washington Withdraws from the ABM Treaty,” International Affairs (Moscow) 48:4 (2002): 77-83. 
warning center; the U.S. considered the radar system to be out-of-date; and so it went. In short, at every turn U.S.-Russian cooperation on this sensitive issue has been deflected or rejected by one side or the other.

We do not think that the then-Russian leadership feared that the U.S. missile umbrella would make United States forces invulnerable to missile attack, and thus would allow their "strategic partner" to strike Russia without fear of retaliation. Most likely they thought that, by holding to the treaty, they had a legal barrier to prevent the United States from developing something more dangerous than just the "limited" shield Bush claimed to want.

In our view, the juridical background of Putin and his closest advisers should be taken into account in any retrospective policy analysis. The Russian leadership under Putin always emphasized warm personal relationships with Western leaders and its respect for existing treaties and international laws_-at least in public. But the idea that a handshake between Putin and Bush could stop the U.S. NMD program seems to us ludicrous.

\section{Rhetoric For and Against Missile Defense}

On 1 May 2001, President Bush said, “This is an important opportunity for the world to rethink the unthinkable and to find new ways to keep peace," alluding to days when the United States and the former Soviet Union threatened each other with massive nuclear arsenals. And then he added: "We need a new framework that allows us to build missile defense to counter the different threats to today's world." But we believe that this is not a new strategy to help "safeguard the U.S. from small but militant states," to use President Bush's words. ${ }^{9}$

There should be no illusion - the deployment of interceptors in Europe is simply a new version of the practice of extended defense. We are using the term extended defense consciously. The tired debate over missile defense brings us back to the strategy of the Cold War. Some older people may remember the concept concerning nuclear weapons as military instruments providing a way to deterrence that was extended geographically. Although the likelihood of nuclear war was rarely particularly high, throughout most of the Cold War this concept was attractive enough to justify the costs of defense systems positioned far from the American mainland. And, as we can see, the old-fashioned concept of extended deterrence remains viable; it has not been replaced with "new concepts of deterrence," as Mr. Bush said. To those observers-including Russians or European - who might have had any doubts about the fundamental reason for the Bush Administration's decision to deploy components of the ABM system, we will provide the following historical parallel that will address their questions.

To put it simply, today's usage of the old concept of extended deterrence shows that the U.S. national security establishment to a large degree remains captive to a Cold War mentality. Cold War habits of thinking die hard. In this case we will not discuss missiles that might be launched from North Korea against the U.S. This scenario is not

9 Washingtonpost.com (online version of the Washington Post for 1 May 2001). 
nearly as interesting for Russian analysts compared with a scenario involving the same missile being launched from a site located in the Middle East, because of such sites' geographical proximity to the main population centers in Russia. If they were intercepted, the North Korean missiles would likely fall into nearby seas or the Pacific Ocean with few if any immediate casualties. ${ }^{10}$

As for a possible attack from the Middle East, Russian military intelligence experts are sure that Iran has no intercontinental missiles capable of reaching Washington, D.C. ${ }^{11}$ Therefore, Russian President Putin strongly opposed the U.S. decision to move a missile defense site close to the western borders of the Russian Federation, because for him there is no need to station interceptors in Europe "in advance." For pragmaticthinking Russians, until Iranian long-range missiles are tested and proven to be operational, they pose no real threat to U.S. security. ${ }^{12}$

Another argument in support of this position comes from estimates for trajectories of missiles originating in Iran. If missiles launched from the Middle East were successfully intercepted by a boost-phase missile defense, it would be very likely that their warheads and/or pieces of incoming rockets and interceptors could kill thousands of innocent people in countries close to the launch site. It would be very unlikely that an intercepted missile with a nuclear warhead would fall within the borders of the country launching a missile, because of the time it would take for both the missile to climb out of the denser part of the atmosphere and for an interceptor to reach it.

To state the case clearly, if the above projections are valid, then it is almost certain that in the event of an attack launched from the Middle East, thousands of people who happen to live along the flight of an incoming missile would be killed. And if anyone believes that the United States really intends to deploy only a limited set of anti-ballistic missiles close to the launch sites to defend their citizens against Iranian attack, then he or she must answer the question: Why it should be done at the expense of Europeans and Russians?

For a long time, President Bush's advisers referred to this project as a national missile system, which implied that it was designed to protect only the United States, rather

10 Needless to say, the consequences of any successful interceptions can be estimated only in terms of possible outcomes. We will not speculate about what would happen to a warhead after a successful boost-phase missile defense engagement: would it detonate or not after the interceptor strikes a target? This issue is beyond the scope of this essay. According to technical experts, the probability of preventing the detonation of the nuclear warhead of an incoming rocket could vary due to a set of factors that will not be discussed here.

11 Russia strongly stands against any “ultimate solution” of the so-called Iranian problem - e.g., a preemptive attack before missiles are launched, or a strike against Iran's nuclear facilities, etc. Such a defense policy could in theory be effective but is unacceptable in practice.

12 The Russian military experts agree that both North Korea and Iran are building ballistic missiles with a range of 3,500-4,000 kilometers or even more, but say the total amount of these long-range missiles will be measured maybe in tens, not hundreds, by 2020-25. They also do not exclude a chance that in the future, a nation's (say, Pakistan) nuclear weapons and missiles might be stolen by Islamic extremists of Al-Qaeda, but doubt that the U.S. missile defenses would help to quell this kind of threat. 
than Europe as well. As I said before, it seems that the U.S. is now seeking its own security at the expense of others. Of course, Bush Administration officials denied this interpretation from the very beginning of this story. On 3 February 2001, at the Munich Conference on European Security Policy, Donald Rumsfeld, then-U.S. Secretary of Defense, said to the European audience: "The United States has no interest in deploying defenses that would separate us from our friends and allies."13

These words were spoken seven years ago. Regrettably, the very idea of deploying such a system has served to separate the Americans from the Russians, who, generally speaking, face the same risk of a potential attack from the Middle East. As we know, the proposal of collaborative missile defense against an attack from the Middle East made by Mr. Putin — which was actually the best variant, politically as well as technologically — was rejected by the U.S. ${ }^{14}$ Perhaps, seven years ago in Munich, Mr. Rumsfeld was addressing his remarks only to Europeans, not to the Russians, who for him were neither friends nor allies. And it is likely that this attitude toward Russia, which was and is widespread among the Bush Administration and the U.S. elite at large, explains a great deal in the entire story: the rhetoric of friendship has been followed by a series of decisions calculated to alienate Russia. ${ }^{15}$ One of these decisions is the construction of a NATO missile defense system, which will be discussed below.

Some Western colleagues may believe that a limited number of U.S.-built landbased interceptors in Europe do not constitute sufficient reason for Russia's concern, but Russia believes that the United States' friends, as well as its enemies, know that devil likes to lie in details.

The U.S. media emphasized the point that the ABM program is "limited," and the number of interceptors is "modest"- - e.g., dozens at first, and maybe near two or three hundred after that. About one hundred of these missiles would be located in Alaska, and a "limited" number in Central Europe and Turkey. In addition to these sites are those interceptors that are or will be stationed on sea-based launching platforms. All in all, it looks like a chain of anti-ballistic missiles along the perimeter of the Russian Federation and the borders of the People's Republic of China. It is a striking reminder of the strategic outlook of the Cold War.

The Russians do not believe that such a configuration of launch sites is designed to defend the U.S. and its allies from North Korean and Iranian ballistic missiles, and that

13 Available at www.defenselink.mil/speeches/2001/s20010203-secdef.htm.

${ }^{14}$ Yet there is little agreement in Moscow as to whether Russia really needs this collaboration, and what it will gain.

15 Concerning this attitude, there is no a great difference between Donald Rumsfeld and two other powerful decision makers in the Bush Administration, Dick Cheney and Condoleezza Rice, or even between him and Gen. Colin Powell, who served in the administration only during the first Bush term. In March 2001, Colin Powell, then-U.S. Secretary of State, told a congressional hearing: “In some ways, the approach to Russia, it seems to me, shouldn't be terribly different than the very realistic approach we had to the old Soviet Union in the late 1980"; see Bulletin of the Atomic Scientists (May/June 2001): 30. 
such a "modest defense is a prudent first step toward countering a known threat." ${ }^{16}$ For the Russians, the additional two to three hundred of the newest U.S.-built interceptors deployed near their borders constitute sufficient reason for serious anxiety.

\section{A Parade of Mistrust}

According to Russian experts, there are strong reasons to believe that the U.S.-built AMD system is oriented basically against Russia and China as the newly emerged missile power of the twenty-first century, not against missiles from Iran or North Korea. U.S. GBI-type interceptors launched from Poland may reach Moscow in eleven minutes. These interceptors have a unique opportunity to eliminate Russian long-range (intercontinental) missiles during the boost phase of flight, just after launch-a capability that the U.S. military had never before possessed. ${ }^{17}$ (The interceptors based in Alaska cannot reach Moscow quickly enough.) And it is absolutely impossible to imagine that the Russian national missile defense system would not react to an interceptor launch from Poland by treating it as an attack from an enemy target, because it could not simply ignore this event as if nothing had happened. Even a limited U.S. missile defense presence in Europe would result in Russia heightening the alert status of its missile arsenal, deploying new multiple warheads, etc.

As for the powerful radar installation in the Czech Republic - the most important element of the In-Flight Interceptor Communications System (IFICS) for controlling U.S. missiles, which, according to Russian experts, might be aimed at Russian strategic missiles - it is also considered to be an instrument that can be used for monitoring military activities in the eastern part of the Russian Federation, including missile launches for various purposes. ${ }^{18}$

Now for a brief aside: a short review of the range of viewpoints on the missile defense issue dominant in present-day Russia gives us a clear understanding that Russian military experts do not believe in the officially declared aims of the European components of the U.S. AMD system. The Russian political elite holds a similar attitude. This suspicious attitude toward U.S. attempts to persuade the Russians in a prolonged dispute over missile defense seems to be a mirror reflection of the traditional U.S. mistrust of the Russians that revealed itself in Mr. Rumsfeld's speech in Munich mentioned above.

In our view, few in Moscow today believe that the mentioned "limited" elements of the AMD system represent an immediate threat to Russian national security. But while these elements were being positioned in Poland and the Czech Republic, despite Russian objections, the Russian authorities resumed talking about the "appropriate responses" to what they consider to be a newly emergent challenge to Russia. This dis-

16 Richard Perle, “The Arms Race Myth, Again.”

17 Vladimir Vasiliev, "Zachem Amerikantsam basi PRO v Evrope? (Why do Americans have Anti-Missile Defense bases in Europe?)” Nezavisimaya Gazeta (27 February 2008); available at www.ng.ru/nvo/2008-02-27/9_pro.html.

18 Ibid. 
cussion was sparked because only very few Russians believe in the idea of collaborative defense against a missile attack from the Middle East.

The political discourse regarding the positioning of the U.S.-built anti-ballistic missile system in Europe has followed the same pattern as the discussion of the U.S. withdrawal from the ABM treaty in 2002, and earlier in the 1980s regarding the Star Wars program. In all three cases, the Russian responses first fell under the rubric of an argument about asymmetry, and the rationale for bringing up this term was to prepare the nation for a new, moderate (by definition), increase of military expenses. The second step in the pattern-at least partly in the last case-is to mobilize public opinion in Poland and the Czech Republic to oppose their national governments on this sensitive issue. The third step is to dissuade the United States and its European allies from pursuing the selected course of action.

The idea behind missile defense has always been to save the U.S. people from the disastrous consequences of nuclear attack. How ironic it is, then, that today there are sound reasons to believe that Russia would be most likely to retarget some of its missiles to Europe as a part of its asymmetric response to this deployment. Unfortunately, there is no evidence that the Bush Administration and the U.S. Congress are concerned about this prospect, or are even aware of it. On the contrary, President Bush is galloping in exactly the wrong direction with his advocacy of the European elements of the AMD system.

The defense ministers of NATO countries at the recent (2008) meeting in Northwick discussed an idea of comprehensive missile defense that can protect all NATO members. Naturally, the Russian observers could not ignore these debates, yet it was simply a conversation about the potential architecture of the entire project. Because again, while thinking about the future, one should answer several basic questions: First, is there a real danger of an offensive missile attack against Europe? Where is such an attack expected to come from? Second, are all member states equally engaged in the project, or do the decisions emanate from just a few countries? And, if this is a case, who in particular, and why?

The conclusions drawn by Russian commentators concerning the perception of threats exposed at that meeting could best be described as original. They argued that, for NATO leaders, the danger to the Alliance does not come from the East, but rather it lies in the East - that is, the threat is not encroaching on Europe, but rather Europe is advancing into dangerous territory.

There is a long historical tradition of Western perceptions of the threat from the East. That conception played an important role in the assessment of Soviet policy and in the planning of Western strategists. As we see, these hoary old threat-perceptions are alive. The deeply rooted prejudice against the Russians or a latent Russo-phobia produced an appeal explicitly to an already-existing traditional threat-perception. Simply put, what determines the actions of the NATO defense ministers is what they think a potential threat looks like, not what it actually is.

We doubt that Russian opposition will slow NATO's planned missile defense implementation. The Alliance is studying the hows, not the whys of this plan. It seems that nobody among the NATO member states ever took seriously the statement made 
by Vladimir Putin, after he was elected as President of Russia in March 2000, that if the West views Russia as an equitable partner, then Russia might, with the passage of time, join NATO.

I will not speculate here about whether Russia is still perceived as the primary threat to NATO, despite numerous declarations about partnership and collaboration and a change in the global geopolitical landscape. Nor will I discuss Russia's deeply rooted mistrust regarding the truthfulness of Western/U.S. policy, which is the foundation of much of the anti-missile defense rhetoric in Russia. Such speculations are fun, but what good are they?

If the U.S. had a completely operational Star Wars missile shield on September 11, would it have saved the Twin Towers? The principal answer is that designing a missile defense system that is sufficient for the purposes of dealing with accidental or unintended launches is merely a technical problem, while dealing with rogue states or fighting international terrorism is a political problem, and this difference is not yet well understood. Therefore, we would agree that the real issue is how to deal with real threats as they emerge, how to develop a true and comprehensive non-proliferation strategy, and how to ensure that global security overall is enhanced rather than diminished by whatever efforts are undertaken. ${ }^{19}$

\section{Non-Collateral Consequences}

The use of sea-based anti-missile weapons against the disabled U.S. intelligence satellite in February 2008 - an event that actually looked more like a test of the interceptor's ability-might serve to provoke accelerated development of anti-satellite weapons in Russia and China, and thus an arms race in space. ${ }^{20}$ Looking back in time, we can remember that, shortly before Mr. Rumsfeld became President Bush's defense secretary and delivered his speech in Munich, he chaired a commission that concluded that "space warfare was virtually inevitable." To "negate the hostile use of space against us," the commission said, "America would need to be able to project power in, from, and through space"- a challenge neither Russia nor China is likely to ignore. ${ }^{21}$ And today, unfortunately, there is a good reason to believe that the likelihood of a new, perhaps even more costly, arms race will keep increasing.

${ }^{19}$ Here we are slightly rephrasing the words of Robert Hunter, the former U.S. Ambassador to NATO, from his Ernest Bevin Memorial lecture at the Atlantic Council of the United Kingdom on 10 February 2001.

20 In fact, Russia/the USSR is a pioneer in this area (a set of successful tests of anti-satellite weapons was conducted in the 1970s and 1980s), but according to sources the Soviets stopped work in this area at the beginning of the 1990s. As for China, this nation has accelerated its anti-satellite weaponry and missile programs in the early 2000s. In 2006, China demonstrated its ability to destroy an object in space, although not with the same skill as the leading space nations. In response to the U.S. plan of TMD deployment in Taiwan, China continues to build up its conventional missile forces. If China is indeed to become "the superpower of the twenty-first century," as some experts argue, the next few years may be vital in its transformation into a great space nation.

${ }^{21}$ Cited in The Economist (5 May 2001): 21. 
Russian defense officials are not afraid of U.S. missile defense modernization; they know that a completely "watertight" missile defense system is technically unfeasible. If the development of a supersonic missile with the ability to penetrate any missile shield, and thus to fully negate the most robust NMD the United States might muster, is an inseparable part of Russia's asymmetric policy response, then defense strategists must remember that the domestic consequences of the Cold War-era arms race for the USSR were catastrophic. ${ }^{22}$ The Russian authorities swear that they will not repeat the mistakes of their Soviet forebears, and it is a pity if these declarations are just words. It is worth remembering that the rest of the world may not see us the way we see ourselves.

It should also be noted that some students of international relations maintain a view that the AMD deployment would not lead to another world-wide arms race because the Cold War doctrine of mutual assured destruction has been dissipated, as both the United States and Russia seek to reduce their reliance on nuclear weapons and address more conventional twenty-first-century threats. Despite the reliance on nuclear deterrence proclaimed in the military doctrines of both the Russian Federation and the United States, nuclear weapons are not the weapons of the twenty-first century. This is due first to the fact that they are weapons of last resort, and, second, to the rapid development of new powerful and precise non-nuclear weapons that can successfully replace nuclear weaponry in certain applications, missile defense systems, and other state-ofthe-art military technologies.

As a result, an arms race defined by the old rules will not materialize in the new century, and therefore the U.S. ABM defense deployments near Russia or China's borders will have little or no effect on the proliferation of weapons of mass destruction (WMD) around the world. Instead, great powers will continue to retool their conventional forces. There is a certain rationale in such a view, yet only the future will show for certain whether the nuclear competition and/or the proliferation of long-range missiles have truly come to a halt. It is true that the threats are different, but the global fear of Iran's military nuclear program confirms that a national nuclear power is still the most valid argument in international affairs that will ensure anyone respectable status on the world stage.

Now for another brief aside: I have referred above to the theory of "mutually assured destruction," or MAD. And we believe that readers have recognized that the deterrence strategies of the Cold War-the concepts of mutually assured destruction and massive retaliation - are not working today. Unfortunately, the logic of MAD has not gone away.

In the Russian view, one serious concern is also a possible (though unlikely) decision by the U.S. to return to a limited nuclear testing regime, because the U.S. has not ratified the Comprehensive Test Ban Treaty (CTB). The famous 2002 U.S.-Russia agreement about reductions of nuclear arsenals must be mentioned in this line as well.

22 These weapons have a unique capability. To be completely correct, the above mentioned project was launched long before the issue of missile defense in Europe became a hot topic. As a rule, it takes several years or even more to develop a new warhead, carrier rocket, or launcher. 
As we know, soon after the U.S. withdrew from the 1972 ABM Treaty, Russia agreed to make major reductions in its strategic offensive missile forces. Today many experts are concerned with questions concerning the future of bilateral arms agreements between the U.S. and Russia: Will the deployment of the small land-based component of the U.S. missile defense system in Europe hinder future arms-reduction deals? To what extent can future reductions in nuclear weapons be negotiated between the United States and the Russian Federation given the dangers posed by an atmosphere of growing mutual mistrust?

\section{Conclusions}

The full content of the Russian asymmetric response to the United States' withdrawal from the AMD Treaty and the deployment of elements of the missile defense system in two Eastern European countries remains unresolved. The efforts by the United States to build missile defenses lead to reactions from Russia, and today there is no question of whether the Russian government could come up with enough money to implement "adequate" responses. The flood of oil money enables Russia to afford a response on the technical level. Indeed, on 18 June 2001, the first time that President Putin announced his reaction after the U.S. missile defense plan was initially revealed to the public, he spoke about upgrading Russia's nuclear arsenal. In particular, Mr. Putin discussed the prospect that Russia would mount multiple warheads on its strategic missiles, and said that Russia would be likely to stop reducing its long-range missile and bomber forces as part of Russia's "asymmetric response." He has repeated his words about an "asymmetric" answer several times during the last seven years, but it seems that Russia's threats were not heard in the West.

In February 2008, Vladimir Putin—at that time on his way out of office (if not out of power) — once again vowed to field new weapons "in response" to the deployment of interceptors in Central Europe. The U.S. media simply laughed at his statement that, with U.S. plans to deploy a limited defense against ballistic missiles, "a new arms race has been unleashed in the world." As Richard Perle wrote in The Washington Post on 3 March 2008, "We should greet Russian threats to race with amusement and a big yawn: They would be competing against themselves. If Putin wishes to pour petro-rubles into building more missiles, our response should be limited to sympathy for the ordinary Russians whose taxes will be squandered, much as they were with catastrophic consequences during the Cold War." The conclusion was that, "with his rhetoric, Putin hopes to excite the opponents of a limited U.S. missile defense system and those politicians here and abroad who will be unnerved by Russian threats of a new 'arms race'," but that he "should relax.",23

This is a characteristic depiction in the Western media of Russia's reaction to the deployment of U.S.-built interceptors in Central Europe. Meanwhile, Putin's threats should not be completely dismissed as rhetoric, as he has been very shrewd in managing Russia's nuclear policy. He supported the ratification of START II by the Russian

23 Richard Perle, “The Arms Race Myth, Again.” 
parliament, and then challenged the United States to agree to deeper strategic nuclear force cuts in a new treaty.

In dealing with this topic, we often find ourselves confronted with a conflict: either we talk and speculate generally about the entire issue, or we examine very concretely, perhaps too concretely, certain detailed aspects of perceptions of Russia's behavior in this particular case. In this paper I have attempted to discuss both the big picture and the more specific evidence with the necessary concentration and brevity.

Most Western observers of the U.S.-Russian dispute about missile defense are concerned with the question of how the growth of Russia's resistance to missile defense systems is linked with Russia's transformation into an "energy superpower." No one should be surprised by such a connection. Western observers often proffer an explanation of Russia's behavior that is couched in economic terms: today, Russia's threats are actually about oil contracts; earlier, they were actually about the repayment of Soviet-era debt. However, in my view, such a simplistic analysis fails to account for Russia's essential motives. Russia's political use of oil and gas exports to Europe is depicted by the Western media as a means for the realization of Russia's ambition to regain its great power status. Meanwhile, in reality the Western countries that consume Russian gas and oil and the Russia that produces and sells these commodities are mutually dependent. Russia always fulfills its energy contracts with the West. As one wise person said, the Russians wouldn't drink their petrol, if the West did not buy it.

We think that the question the media are pursuing concerns not the essence of present Russian foreign and energy policy, but rather an image of Russia that is conveyed by the press in the West. As was mentioned above, the image of Russia as a re-emerging threat to European security is a result of a complex process of image-building, one that is more dependent on historical traditions than on present-day facts and prospects. Nevertheless, this specific image that many in the Western political elite have of Russia forms part of the foundation on which media comments and political decisions are based. It seems that even the concessions to the U.S. made by Mr. Putin in the early 2000s appear not to have created any fundamental change in perceptions.

The political problem can be best framed as, How much of President Putin's postSeptember 11 policy is Russia ready to abandon in response to the deployment of interceptors in Central Europe? I will not discuss this question here, although the reader might try to answer this question him- or herself. ${ }^{24}$

${ }^{24}$ It seems that in the early 2000s Putin held illusions regarding the consistency of missile defense policy, and maybe even thought that Bush's intentions could be changed by a combination of Russian objections and concessions. After the U.S. withdrew from the ABM treaty in 2001, Moscow's response, delivered in a statement by Putin, expressed disagreement with the U.S. decision but diplomatically emphasized the official position that U.S. is not a threat to Russia. After the events of 9/11, Putin allowed the U.S. to construct airbases in former Soviet republics in Central Asia, and did not actively hinder the war against the Taliban in Afghanistan. Then, in 2002, Russia agreed to sign a new treaty on the reduction of U.S. and Russian nuclear arsenals. 
The course of a nation's foreign policy is said to be the sum of that country's geography, history, and resources. Such a policy course includes a foreign policy geared to a nation's interests, memories, and values. The dilemma of Russia's size and the current dynamism of its economy are crucial for the years to come. As a matter of fact, the Russian Federation - much like the Soviet Union in the days of the Cold War-relies upon nuclear weapons as risk-minimizing military instruments. The possession of a significant nuclear arsenal gives the Russians a chance to compete with the West economically and to be treated as equals politically; this is a popular position of those who prefer thinking in terms of security that is guaranteed through the ability of assured destruction of any potential rival by nuclear missiles. But isn't this way of thinking simply realpolitik all over again?

On Russia’s political agenda, the debate around the ABM issue is mixed with a discussion of steps aimed at modernizing the Russian armed forces and creating renewed components for the Russian missile program. It is really an unfinished discussion, yet it has been poorly reported in the West, where it has too often been caricatured and misinterpreted. $^{25}$

The recent debate in the Russian media concerning the coming deployment of the missile defense system components in Central Europe has been driven by a tiny group of military commentators, while the public has played a negligible role. As Russian objections have been ignored once again, many ordinary Russians, following Putin's anti-Western rhetoric, believe the U.S. is still pushing its old security agenda, and that the Bush Administration is pursuing a methodical anti-Russian policy. In fact, the U.S. NMD plan served as a powerful impulse to frighten the Russian public into sacrificing more for the nation's defense. The bulk of Russian policy-makers and observers have been almost universally hostile to the new U.S. and/or NATO bases near the Russian borders (in Bulgaria, etc.); their attitude toward the deployment of U.S. interceptors in Poland, along with the radar station in the Czech Republic, was predictably negative. Meanwhile, it seems that Russian military analysts have realized that Russia cannot do much about it. This follows the same pattern of behavior that was revealed during lengthy debates in Russia on NATO enlargement eastward in 1990s, the Kosovo crisis in 1999, and after President Bush's announcement of the NMD plan in 2001.

The Russians felt humiliated yet again, but could do nothing to prevent the deployment. Would they finally let the problem drop quietly? It is an open question, although one can foresee no profound actions coming from the Russian side. Perhaps this is because the missile issue does not concern Russia's vital interests.

25 See, for instance, Robert Joseph and J.D. Crouch II, “Moscow’s Missile Gambit,” The Washington Post (13 March 2008): A17. The authors attempted to analyze the U.S. and Russian stands in the dispute on missile issue, praised the U.S. position, and finally came to the very trivial conclusion: "Moscow is eager to regain its great-power status and thinks the path to success requires painting the United States as the threat. ... On missile defense, the United States must move forward, just as Russia does when its vital interests are at stake. We should continue to be respectful and transparent about the need for our deployments but make clear that the United States will proceed without Moscow’s cooperation.” 
This kind of behavior matches the course of Russian foreign policy course since Vladimir Putin came to power. Only after the United States withdrew from the 1972 ABM Treaty (continued adherence to which was a condition specified in the Russian START II ratification law) did Russia announce that it considered itself no longer bound by the provisions of START II. Due to the ABM project-at least in partU.S.-Russian relations have been deteriorating for some time, and Russia has been drifting away from the West in general, as demonstrated by its unilateral withdrawal from the Conventional Forces in Europe (CPE) Treaty. There also have been predictable differences over the issue of Kosovo's independence at the UN Security Council meetings. Alas, nothing of all that has been mentioned has been anything new.

To conclude, the Bush team came to office obsessed with building a ballistic missile shield. The temptation of missile defense became a harsh lesson for Russia's president. However, let us not forget that the issue of missile defense is just a part of the broader context of international relations. And let us hope that responsible Russian leadership—in particular the newly elected Russian president, Dmitry Medvedev, ${ }^{26}$ as well as Russian society at large-will seek to avoid "freezing" Russian cooperation with Europe, and will not push the country toward a new military and political confrontation with the United States. We think that a new national leader cannot craft policy on the assumption that the future will largely resemble the past, because then any changes will come as a shock for which Russia is not prepared.

The old appeals to understand the other side-i.e., the motivations and interests as they apply to the missile defense issue - and to offer a mutually acceptable solution are vital today as never before. Otherwise, we believe that missile defense systems, while redefining deterrence, are nevertheless part of discredited security paradigm, and will lead to greater global instability, and not to the abolition of weapons of mass destruction and their delivery systems through diplomacy.

Postscript: This article was written in March 2008. Six months later, its predictions are becoming a reality. It is still too early to speak of what the Russian counter-actions against the deployment of the U.S. missile defense bases in Poland and the Czech Republic might be. Therefore, it is impossible to discuss what measures will be taken by the Russian Federation. Appropriate decisions will be made by the Medvedev Administration depending on information obtained. But, whatever they may be, these actions cannot solve the missile defense problem in the long term.

${ }^{26}$ This text was written soon after the 2008 presidential elections in Russia. 
FALL 2008

\section{Bibliography}

S., Kortunov. "Washington Withdraws from the ABM Treaty." International Affairs 48, no. 4 (2002): 77-83. 